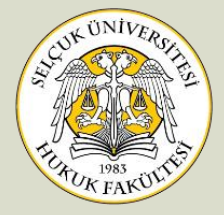

\title{
3D PRINTING, ARTIFICIALLY INTELLIGENT ROBOTS AND SOFTWARE INVENTIONS, IS TECHNOLOGY SHAKING THE REIGN OF IP LAW?
}

\author{
Muhammet Emir ÇELIK*
}

\begin{abstract}
Intellectual property (IP) rights have always had difficulties to cope with disruptive technologies. Development of AI-implemented works and common use of it pushes the boundaries of IP protection. Increase of machines which can independently act or create things have posed a numerous concern of patent system such as how will the inventive step, prior art, inventorship and technical contribution evaluated. Nevertheless, the grey area is how patent holders will protect their rights on products against direct and indirect infringement which can also made by 3D printers. This article analyses that the question of is the current patent regime sufficient to evaluate software-implemented works, 3D printing and Robotics to detect potential infringements and reaches the conclusion that it does not seem to be answered affirmatively based on current regulations. This article argues that some legal regulations should be done to overcome the uncertainty of AI generated works' protection scope.
\end{abstract}

\section{Key Words}

IP $\bullet$ Patent $\bullet$ Robots $\bullet$ 3D printing $\bullet$ Software inventions

* $\quad$ LL.M, Avukat, İstanbul Üniversitesi, Özel Hukuk Doktora Öğrencisi, İstanbul, Türkiye| LL.M. Advocate., Istanbul University, Private Law PhD student, Istanbul, Turkey.

囚emir@mmcelikpartners.com • ORCID 0000-0001-7247-174X

Atıf Şekli | Cite As: ÇELIKK Muhammet Emir, "3D Printing, Artificially Intelligent Robots and Software Inventions, Is Technology Shaking the Reign of IP Law?", SüHFD., C. 29, S. 4, 2021, s.3325-3348

İntihal | Plagiarism: Bu makale intihal programında taranmış ve en az iki hakem incelemesinden geçmiştir. I This article has been scanned via a plagiarism software and reviewed by at least two referees. 


\section{D BASKI, YAPAY ZEKALI ROBOTLAR VE YAZILIM ICATLARI, TEKNOLOJI FIKKRI MÜLKIYYTT HUKUKUNUN SALTANATINI SARSIYOR MU?}

Öz

Fikri Mülkiyet hakları yenilikçi teknolojilere ayak uydurmakta her zaman zorlanmıştır. Yapay zekâ içeren çalışmaların gelişimi ve toplumsal kullanımı, fikri mülkiyet korumasının sınırlarını zorlamaktadır. Bağımsız olarak hareket eden ve üreten makinelerin artması buluş basamağı, buluş öncesi teknik durum ve teknik katkının nasıl değerlendirileceği gibi sayısız patent sistemi endişesini ortaya çıkarmıştır. Bununla birlikte, patent sahiplerinin ürünler üzerindeki hak-larını, 3D yazıcılar tarafından da gerçekleştirilebilen doğrudan ve dolaylı ihlalle-re karşı nasıl koruyacakları gri bir alan teşkil etmektedir. Bu makale, mevcut patent rejiminin potansiyel ihlalleri tespit etmek için, yazılımla yapılan çalışmaları, 3D baskıyı ve Robotik çalışmaları değerlendirmede yeterli olup olmadığı sorusunu analiz etmekte ve mevcut düzenlemelere göre olumlu bir şekilde cevaplanmadığı sonucuna varmaktadır. Bu makale, yapay zekâ kaynaklı eserlerin koruma kapsamının belirsizliğini aşmak için bazı yasal düzenlemelerin yapılması gerektiğini savunmaktadır.

\section{Anahtar Kelimeler}

Fikri Mülkiyet • Patent $\bullet$ Robotlar $\bullet$ SD yazıcı $\bullet$ Yazılımsal buluşlar

\section{Introduction}

Technological evolution in the 21st century made way for radical changes in our lives. Last century was popular for computer and communication developments, but nowadays it seems that artificial intelligence (AI) is able to improve every machine to generate products such as robotics, 3D printing machines and computer implemented innovations. Although there is no commonly used definition for AI, it mostly used for problem solving task inspired from human brain. ${ }^{1}$ It can be understood how AI innovation will increase by looking at the $90 \%$ rate of allowance

1 CUBERT Jeremy., "The Law of Intellectual Property Created by Artificial Intelligence" in Barfield Woodrow and Pagallo Ugo, "Research Handbook on the Law of Artificial Intelligence“ Edward Elgar Publishing, 2018 417. <https://www.elgaronline.com/view/edcoll/9781786439048/9781786439048.00028.xml> accessed 26 April 2020 . 
in PTO 7-year period from 2011. ${ }^{2}$ Even though EPO recommendations and many scholars expressed that current regime is sufficient to deal with new disruptive technologies ${ }^{3}$ some argue that in the light of technological growth in the AI industry it is important to beware that existing inapplicable frameworks must be re-evaluate. ${ }^{4}$ From the point of software, although computer programs are excluded from patentable subject matter, there is a legal uncertainty how broad this term should be understood and whether to assess AI-based products with the current requirements. Increase of machines which can independently act or create things have posed a numerous concern of patent system such as how will the inventive step, prior art, inventorship and technical contribution evaluated. Patentability requirements especially inventive step and non-obviousness had been set to prevent numerous worthless progress in the patent system. The aim of requirements was to eliminate inventions will be invented even patent system not exist. ${ }^{5}$ Conversely, accepted technical contribution approach seems to increase the number of patents in the field. The aim of patent regime is sharing developments with the society to protect sustainability of development, there while protecting inventor's idea and

2 SUTTON Eric, “Artificial Intelligence 2.0: Artificially Intelligent Guidance for Obtaining Artificial Intelligence Patents, as Presented to IPO (3-7-18) $<$ http://www.patnotechnic.com/2018/04/artificial-intelligence-20-artificially.html> accessed 26 April 2020.

3 MIMLER Marc, "3D Printing and Patent Law - a UK Perspective: Apt and Ready?" in Mendis Dinusha, Lemley Mark and Rimmer Matthew, "3D Printing and Beyond" Edward Elgar Publishing, 2019 21. <https://www.elgaronline.com/view/edcoll/9781786434043/9781786434043.00012.xml> accessed 16 May 2020.

4 DEPOORTER Ben, "Intellectual Property Infringements \& 3D Printing: Decentralized Piracy Symposium: The Legal Dimension of 3D Printing“ Hastings Law Journal, 65, 2013 1483,1489 <https://heinonline.org/HOL/P?h=hein.journals/hastlj65\&i=1595> accessed 26 April 2020.

5 KITCH Edmund W., “Graham v. John Deere Co.: New Standards for Patents“ Journal of the Patent Office Society, 49, 1967 237,246. <https://heinonline.org/HOL/P?h=hein.journals/jpatos49\&i=263> accessed 26 April 2020. 
incentive. To redress the balance between this two, it is essential to regulate wideness scope of protection. ${ }^{6}$

Furthermore, it is claimed that compared to high R\&D costs, profit planned to gain from patent rights might be less because of rapidity of technology. ${ }^{7}$ For instance, 3D printing provides almost zero cost to copy products with the downloadable file. Producing objects via 3D is infringe the patents except private use however, it is not clear whether sharing CAD files infringe the rights. It is essential for patent holders to prevent the dissemination of CAD files because of detecting and cost difficulties of individual infringements. Under current law there are many questions and ambiguity in practice area of 3D printing. After the foundation of internet, Laws transformed to keep up with the technology, it is expected that with 3D machines the same will happen. Although it is necessary to ensure protection for patent holders, if protection to the claimant will too strong then the market price and crooks would be too much. Also, 20-year protection will be ease and much more then patent holder deserved. ${ }^{8}$ Although it has been stressed that patent system need reformation incentivizing innovation there is no evidence that reconfiguring system will provide ideal concept. It is argued that rather than tailoring the patent system eligibly to innovation, some deep principles of system must be change completely. ${ }^{9}$ Because rapid growing in technology showed that there

6 RAMALHO Ana, "Patentability of AI-Generated Inventions: Is a Reform of the Patent System Needed?" Social Science Research Network, 2018 8. <https://papers.ssrn.com/abstract=3168703> accessed 26 April 2020.

7 GOLDMAN Eric, "Fixing Software Patents" Social Science Research Network, 2013 5-7. <https://papers.ssrn.com/abstract=2199180> accessed 26 April 2020.

8 BECKER Gary and POSNER Richard, “Do Patent and Copyright Law Restrict Competition and Creativity Excessively?" The Becker-Posner Blog, 2012 $<$ https://www.becker-posner-blog.com/2012/09/do-patent-and-copyright-law-restrict-competition-and-creativity-excessively-posner.html> accessed 26 April 2020.

9 JAFFE Adam and LERNER Josh, "Innovation and Its Discontents: How Our Broken Patent System Is Endangering Innovation and Progress, and What to Do About It" Princeton University Press, 2004 198. <https://www.jstor.org/stable/j.ctt7t655> accessed 26 April 2020. 
always been new technological innovations and it is not possible to adapt law at every turn. ${ }^{10}$

In this essay it is aimed to assess the difficulties IP system expected to face against last developments in $\mathrm{AI}, 3 \mathrm{D}$ printing and robotics in terms of patents and to reach a conclusion whether the current patent evaluation in this fields need to change. This essay divided into three main parts. In the first part it will examined that whether using 3D machines, sharing digital files infringe the patent protection and how will system protect patent holders. Second part consists of how patentability requirements of inventions can implement to software implemented inventions and challenges about assessing technical effect, person skilled in art and AI inventorship. Third part will analyse the consequences of potential infringements robotics may cause and strategies firms follow. Finally, it will be summarised that how new technologies shape the current patent policy.

\section{3D PRINTING}

3D printing defined as form of creating objects from digital codes, additive manufacturing. ${ }^{11}$ 3D printing is an alternative method for manufacturing wide scope of goods. With the disposability of $3 \mathrm{~d}$ printers in homes, it seems that the economic system we are familiar with most likely to change. ${ }^{12}$ To manufacture anything with 3D machines, there are two way, one of them is using software made CAD files or to have a digital copy using $3 \mathrm{D}$ and scanning (reverse engineering) the object. It is clear that by using 3D printers it is possible to create novel products as well as recognized ones. In terms of patentability, only if completely new substance designed, infeasible to do by conventional techniques means it is novel and, on the condition, that other requirements of patentability is

10 ibid.

11 BALLARDINI Rosa Maria, NORRGÅRD Marcus and MINSSEN Timo, "Enforcing Patents in the Era of 3D Printing“ Journal of Intellectual Property Law \& Practice, 10, $2015 \quad 850,850 . \quad<$ https://academic.oup.com/jiplp/article-lookup/doi/10.1093/jiplp/jpv152> accessed 26 April 2020.

12 WHADCOCK Ian, "A Third Industrial Revolution" The Economist, 2012<https://www.economist.com/special-report/2012/04/21/a-third-industrial-revolution> accessed 26 April 2020. 
fulfilled, it can be patented. ${ }^{13}$ Due to limitations of this study, this part will mostly focus on direct and indirect infringement. However, the most concerning question is how patent holders will protect their rights on products which can also made by 3D printings. Detecting direct infringement in an individual base is complex, difficult and costly therefore It is argued that there is increasing intention on indirect infringement to protect patents. ${ }^{14}$

\section{a) Repairment}

Section 60(1) of UK patent act defines the actions of direct infringement, one of them is making the patented product. ${ }^{15}$ In the United Wire Ltd v Screen Repair Services case, it is stated that in patent system there is no 'implied right to repair' however, it is unclear that whether repairing product means 'making' and infringement. ${ }^{16}$ Although, Mendis argue that repaired product can be seen as a new edition and infringe the patent ${ }^{17}$, Betchold argue that the act of repair and make are differentiated in nature hence repairing doesn't infer infringement. ${ }^{18}$ Both in statuaries and cases it is not clear that, if the products of 3D printer user need to be repaired and how will this action distinguish from an infringement. ${ }^{19}$

\section{b) Responsibility of Intermediaries}

It is argued that print the object and ship it to the customer is direct infringement while customizing the CAD file is an indirect infringement

13 OVERWALLE Geertrui Van and LEYS Reinout, “3D Printing and Patent Law: A Disruptive Technology Disrupting Patent Law?" IIC - International Review of Intellectual Property and Competition Law, 48, (2017) 504,514 <http://link.springer.com/10.1007/s40319-017-0602-1> accessed 26 April 2020.

14 BALLARDINI, NORRGÅRD and MINSSEN (n 11) 856.

15 UK Patent Act 1977 s 60(1).

16 United Wire Ltd v Screen Repair Services Ltd [2001] RPC 24.

17 MENDIS Dinusha, ““The Clone Wars”: Episode 1: The Rise of 3D Printing and Its Implications for Intellectual Property Law - Learning Lessons from the Past?“ EIPR: European Intellectual Property Review, 35, 2013 155,160.

18 BECHTOLD Stefan, “3D Printing, Intellectual Property and Innovation Policy" IIC International Review of Intellectual Property and Competition Law, 47, 2016 517,528. <http://link.springer.com/10.1007/s40319-016-0487-4> accessed 26 April 2020.

19 MENDIS (n 18) 161. 
regarding provided additional service by online platform. ${ }^{20}$ Due to high cost of complaining direct infringers it may be better to hold mediators liable. At every time of printing objects by 3D machine patent rights will be infringed. Nevertheless, by doing this, it is notable to consider intermediaries are playing effective role for market by facilitating distribution. ${ }^{21}$ To execute the infringement, it is required to know the object is patented. The 'knowledge' criteria doesn't seem convenient, due to extreme workload of print officers and there is no list of goods because it depends on demand..$^{22}$ Staple Article of Commerce Doctrine supports that if it can be also used for private reasons there would be no contribution to the infringement. ${ }^{23}$

\section{c) Private Use Exception}

In contrast to USA, most of the countries in Europe for example, UK Patent Act 60(5)(a) excluded private use from the scope of patent infringements. ${ }^{24}$ Also the Art.30 of TRIPS stated that rather than supplying or offer to supply if the person use CAD files for private use then indirect infringement will not likely occur. ${ }^{25}$ It is argued that the main aim of this exception is the assumption that patent holder won't be harmed by this. ${ }^{26}$ This all matter of how many people adapt with this technology. For example, if 10.000 customer start to generate the object $x$ by 3D machines when considering the audience scope of the particular market, it can be seen that the damage patent holder would get will be deadly. ${ }^{27}$ Not restricting the

\footnotetext{
$20 \quad$ VAN OVERWALLE and LEYS (n 13) 528.

21 BECHTOLD (n 19) 530.

22 OSBORN Lucas, "3D Printing and Intellectual Property" Cambridge University Press, 1st edn, 2019 89. <https://www.cambridge.org/core/product/identifier/9781316584507/type/book> accessed 26 April 2020.

23 VAN OVERWALLE and LEYS (n 13) 526.

24 UK Patent Act 1977 s 60(5)(a); Jones v Pearce [1832] 1 WPC 122.

25 Agreement on Trade Related Aspects of Intellectual Property 1994, Art.30

26 SHERMAN Brad, "Exclusions from Patentability and Exceptions and Limitations to Patentees' Rights" WIPO Standing Committee on the Law of Patents, 2010 SCP/15/3 Annex $\quad 2 \quad 7 . \quad<$ https://www.wipo.int/edocs/mdocs/patent_policy/en/scp_20/scp_20_3.pdf>.

27 OSBORN (n 20) 86.
} 
usage, clearly conflicting with the aim of patent system. One of the reasons infringements take place in 3D printing products except using for commercially, is to sustain development in the field because manufacturing with the 3D printers is low cost and faster, so the conventional producers cannot balance R\&D costs.

\section{d) Are CAD Files Software or "Means"}

3D printing machine works with several files such as surface-mesh files, design files and machine-instruction files. The connection between 3D printer and machine-instruction files is comply with the 'further technical effect' which software creates on hardware as patentability requirement as it stated in IBM case however, design and surface-mesh files have problems because of indirectness. ${ }^{28}$ However, non-patented item can be 'means' of supplying and cause infringement if it is intended to put the patented object into force. ${ }^{29}$ Accepting CAD files as codes or intention to create objects, differentiate in the mean of whether sharing CAD files violate patent rights. It is argued by Mendis ${ }^{30}$ that supplying 'means' may be equal to procure CAD files however, Bradshaw ${ }^{31}$ argue that it must be understand broader such as procuring design file, material and 3D printer. Mostly, in history, courts interpreted this term as tangible elements rather than abstract instructions. Sharing CAD files won't mean violate the patent rights according to the conventional approach which accept CAD files as codes. Nevertheless, it is not clear that the cad files are software on their own, yet to create them it is necessary to use cad software. Some of the experts argue that such files are artistic creations while some argue software. ${ }^{32}$ In the case of patent infringement claim in

28 T 1173/97 (Computer program product/IBM) of 1.7.1998. 5.3

29 UK Patent Act 1977 s 60(2).

$30 \quad$ MENDIS (n 17) 160.

31 BRADSHAW Simon, BOWYER Adrian and HAUFE Patrick, "The Intellectual Property Implications of Low-Cost 3D Printing“ A Journal of Law, Technology and Society, 7, 2010 5,14. <https://heinonline.org/HOL/P?h=hein.journals/scripted7\&i=5> accessed 26 April 2020.

32 RIDEOUT Brian, "Printing the Impossible Triangle: The Copyright Implications of Three-Dimensional Printing“ Journal of Business, Entrepreneurship \& the Law, 5, 
Menashe Business Mercantile Ltd v. William Hill Organisation Ltd, although the host computer was abroad the program can run in the devices of customers in UK, and court held that supplying the program is an 'essential element' thus infringing the patent. ${ }^{33}$

\section{e) Essential Element of Invention}

Is it possible to announce the elements which are not in the claim of application as essential elements? It is not clear what makes an element 'essential' due to a smaller number of cases in this topic. Courts in UK held that, it should depend on whether invention can be used without it, to understand whether the element is essential. ${ }^{34}$ It is not clear that only providing CAD file is sufficient to indirect infringement while users also need 3D printer and materials. But it must be highlighted that in terms of decreasing cost and facilitation CAD documents are indispensable. In order to be indirect infringement, it is not required to be brought the invention into force it is enough to satisfy the conditions in terms of 'means' of essential element. ${ }^{35}$ Making utilisable the CAD document via internet does mean bringing the invention into force? It is argued by Mimler that, in the situation the customer can print the object based on supplied CAD document, indirect infringement will occur while if it is as easy as pushing a button then it will be direct infringement. ${ }^{36}$ Also, in Actavis Ltd v. Eli Lilly \& Co. ,UK Court have decided that it is not necessary to have the exact raw material to infringe the patent, any means can be used for same purpose is also sufficient. ${ }^{37}$ However, 'suitability' and 'intention' criteria are difficult and complex to follow. In case of technical drawings shared

2011 161,165 <https://heinonline.org/HOL/P?h=hein.journals/jbelw5\&i=163> accessed 26 April 2020.

33 Menashe Business Mercantile Ltd and Another v William Hill Organisation Ltd [2002] EWCA Civ 1702, [2003] 1 WLR 1462

34 BALLARDINI, NORRGÅRD and MINSSEN (n 13).

35 ibid 860.

36 MIMLER Marc, "3D Printing, the Internet and Patent Law - A History Repeating?" Social Science Research Network, 2013 352,358. <https://papers.ssrn.com/abstract=2482551> accessed 26 April 2020 .

37 Actavis UK Ltd and Others v Eli Lilly and Company [2017] UKSC 48, [2018] 1 All ER 171 
and the customer needs technical ability, UK courts has assessed that subjective criteria should be disregarded while assessing infringement. ${ }^{38}$ Furthermore, to bring an infringement, person should know it or it should be clear from the situation that the supplied CAD file have planned to use in a manner of infringement by the customer. ${ }^{39}$ Even though CAD files generally use in this sense, it also uses for many other purposes, thus knowledge requirement doesn't seem appropriate benchmark. Despite it will assessed case by case basis, it is hard to read intention. ${ }^{40}$

\section{AI AND SOFTWARE IMPLEMENTED INVENTIONS}

\section{a) Technical Contribution}

Although in USA, in Diamond v. Chakrabarty case ${ }^{41}$ Supreme court decided that "anything under the sun that is made by man" is the patentable subject matter threshold, in Europe, Article.52/1 of EPC ${ }^{42}$ regulated patent requirements as newness, inventiveness and deployment in industry. EPC 52/2 stated that computer programs are not patentable while 52/3 stated that inventions 'as such' are not patentable. ${ }^{43}$ It is not clear what is referred by computer programs and 'as such'. The 'as such' term has interpreted as: not all the computer programs but only abstract ideas which don't have a technical character are not patentable. ${ }^{44}$ It is agreed that 'as such' amount to non-technical advancements otherwise if the application fulfil other patentability criteria's especially the technical one then it means invention is patentable. ${ }^{45} \mathrm{EPO}$ has followed two main approaches.

Firstly, technical effect approach is further technical contribution to the prior art. It is stated that usual electrical interactions is insignificant to distinguish among computer programs which has technical feature and

\footnotetext{
38 Rabobank New Zealand v McAnulty [2011] 3 NZLR 192 (CA)

39 BALLARDINI, NORRGÅRD and MINSSEN (n 11) 864.

$40 \quad$ ibid 865.

41 Diamond v. Chakrabarty - 447 U.S. 303, 100 S. Ct. 2204 (1980)

42 European Patent Convention (EPO) Art. 52/2

43 Ibid.

44 T 1173/97 (Computer program product/IBM) of 1.7.1998. 5.2

45 CRISTINA Ionita, "Software Patentability in Europe: The Rise of the Inventive Step Requirement" UPPSALA UNIVERSITET, 201710.
} 
'as such' ones. ${ }^{46}$ EPO has stated that it would not exempt from patentability, if computer program has used for software invention, but requires technical contribution to the prior art in an out of the exclusion field to qualify as patentable. For instance, VICOM ${ }^{47}$ increased display quality, in digital, by mathematical methods thus, patented. Enough technical feature cannot be provided only by using computer for instance, correction in out of the exclusion field such as word processing even in computer programs decided as unpatentable. ${ }^{48}$ (IBM/Text processing).

However, in IBM/Computer program product case ${ }^{49}$, it is decided that programs on their own or in transporter are patentable. In sum Board has changed his direction because 'technical contribution' approach cause complexity between what requisite the invention and requirements of inventive step and novelty. ${ }^{50}$ Without considering prior art and pointing the underlying cause, evaluating patentable subject matter has been criticised. ${ }^{51}$

Secondly ,Technical Boards of Appeal changed the direction towards to any-hardware approach, supports that the claim should be in or should involve the physical components which not necessary to be new to have technical character. ${ }^{52}$ Court of Appeal in UK decided that if the subject of claim had excluded from the patentability, application would be refused..$^{53}$ Also, the Board decided that solution in excluded field were not characterised as a technical feature. ${ }^{54}$ Thus, although the solution is non-obvious, inventiveness in different area means there is lack of inventive step. ${ }^{55}$ In contrast, in Microsoft case, court held that by helping the

\footnotetext{
$46 \quad$ T 1173/97 (Computer program product/IBM) of 1.7.1998

47 T-208/84 VICOM/Computer-related invention [1987] 1 OJEPO 14

$48 \quad$ T-65/86 IBM/Text processing [1990] EPOR 181

49 T-935/97 IBM/Computer program product II [1999].

$50 \quad$ IONITA (n 43) 11.

51 T-931/95 PBS PARTNERSHIP/Controlling pension benefits system [2000] OJ EPO 441

52 IONITA (n 43 11).

53 Hitachi/ Merrill Lynch's Application [1989] RPC 561; Gales' Application [1991] RPC 305

54 T-931/95 PBS PARTNERSHIP/Controlling pension benefits system [2000] OJ EPO 441

55 T-0258/03 HITACHI/Auction Method [2004]
} 
data transaction between programs, contribution to computer system in terms of internal transaction is technical, thus, subject methods are patentable. ${ }^{56}$ It is argued that liberalisation of patent system may weaken the rule of subject matter eligibility thus the quality of patents however, $\mathrm{Mu}$ nich approach claimed that directing the focus from qualifications of subject matter to advanced level of technical contribution and inventiveness could enhance the level for computer generated innovations and also decrease the immediate refuse of contribution to prior technic. ${ }^{57}$ It has seen that the quality of patents has endangered in the long term in the way how patent system assesses the procedure. The disharmony of courts' approach to cases, brought questions related whether the principles of patent system is enough to assess the developments in this area.

\section{b) Inventorship}

The common view in Current Patent law acknowledge natural persons as an inventor to apply for their innovation. ${ }^{58}$ If autonomous computers, make an invention without human intervention, who will be allocated as an inventor ${ }^{59}$ Computers also don't have a legal personality, so it is not possible to allocate them as an inventor. But also, it is not logical to give protection to human who operates the AI for produced work because that means too much protection. ${ }^{60}$ Inventor is the person who design the invention in his mind, but it is not required inventor to put it in to practice. ${ }^{61}$ Although there are some software-generated product examples such as creativity machine which can operate without human intervention they patented on behalf of human who programmed them.

\footnotetext{
56 T 0424/03 (Clipboard formats I/MICROSOFT) 23.2.2006 5.3

57 G 03/08 (Programs for computers) EPO 12.5.2010; Brad n(28).

58 SOANS Cyril, "Some Absurd Presumptions in Patent Cases" Patent, Trademark and Copyright Journal of Research and Education, 10, 1966 433,438. <https://heinonline.org/HOL/Page?handle=hein.journals/idea10\&id=435\&div=\&collection=>.

59 ABBOTT Ryan, "I Think, Therefore I Invent: Creative Computers and the Future of Patent Law" Boston College Law Review, 57, 2016 1079,1121. <https://heinonline.org/HOL/Page?handle=hein.journals/bclr57\&id=1080\&div=\&collection=>.

60 ibid 1085.

61 Cooper v. Goldfarb, 154 F.3d 1321, 1327 (Fed. Cir. 1998)
} 
However, it is argued by scholars that there is no sufficient ground for liberalizing AI regime, the current system, limiting inventorship is enough for the mid-term future. ${ }^{62}$ Although even if the technology reaches the level of independent innovation of machines the identification of AI regime as an inventor may not be possible. ${ }^{63}$ Even though currently machines are not be able to perform wholly independent, soon it is expected that they will be able to innovate completely separate from instructions and commands and be able to apply for their patent requests. ${ }^{64}$

It is not clear how patent law will deal with when computers start to produce inventions autonomously. Complication between current laws' ${ }^{65}$ intensity of allocating natural persons as a right owner and independent creativity ability of machines seems cannot solved by traditional patent law principles. ${ }^{66}$ There must be some changes at inventor requirements to place the innovations in the system. AI systems consist contribution of many players which are connected to each other to support performing system. Inventorship can be claimed by those people whose are software programmers who developed the program without specific target, data suppliers who trains the machine for learning ability, the owners of the AI system, the operators or people who have licenced to use the system, the investors who afford the investment costs. ${ }^{67}$ In patent application it is required to show the usefulness, non-obviousness, inventiveness and novelty features of innovation. As these requirements fulfilled it can be argued that $\mathrm{AI}$ or anybody may receive a patent. ${ }^{68}$ However as for

62 VAN OVERWALLE and LEYS (n 13) 529.

63 SHEMTOV Noam, "A Study on Inventorship in Inventions Involving AI Activity" Queen Mary University of London, 201934.

$64 \quad$ ABBOTT (n 51) 1081.

$65 \quad 1977$ Patents Act s(7)

66 RUSSEL Stuart and NORVIG Peter, “Artificial Intelligence: A Modern Approach" Pearson Education Limited, 2013938.

67 RAVID Shlomit Yanisky and LIU Xiaoqiong, “When Artificial Intelligence Systems Produce Inventions: An Alternative Model for Patent Law at the 3A Era" Cardozo Law Review, 39, 2018 2215,2233.

68 KARKHANIS Aashish and PARENTI Jenna, "Toward an Automated First Impression on Patent Claim Validity: Algorithmically Associating Claim Language with Specific Rules of Law“ Stanford Technology Law Review, 19, 2015 196,201. 
now, when applying a patent application involving an $\mathrm{AI}$ inventor it is most likely to rejected by article 19 and 81 of EPC. ${ }^{69}$

\section{c) $\mathrm{AI}$ as a PHOSITA}

Increasing AI systems will most challenge with inventive step and non-obviousness requirements of patentability. ${ }^{70}$ To be patentable in article 56 it is required that invention "is not obvious to the person skilled in the art, having regard to any matter which forms part of the state of the art. ${ }^{71}$ Patent examiners mostly consider former fillings to decide whether matter of innovation is new while neglecting favourite doctrines and teachings. ${ }^{72}$ This process may occur conflicts in AI patents because of inadequate understanding and may show up as patenting existing technologies and preventing potential future development, unwitting infringements and decreasing the quality of patents due to lack of intensive research. ${ }^{73}$

Raising the patentability threshold may be one solution and excluding the inventions generated out of the patent regime in subcategory may be the other. ${ }^{74}$ However, this may cause arbitrariness in the AI inventions. ${ }^{75} \mathrm{It}$ is argued that the level of inventor ability has rose by the AI so average

$<$ https://heinonline.org/HOL/Page?handle=hein.jour-

nals/stantlr19\&id=212\&div=\&collection $=>$.

69 European Patent Convention (EPC) Art.19,81

70 GRANSTRAND Ove, "Patents and Policies for Innovations and Entrepreneurship" in Takenaka Toshiko, "Research Handbook on Patent Law and Theory“ Edward Elgar Publishing, $\quad 2019 \quad 86 \quad<$ https://www.elgaronline.com/view/edcoll/9781785364112/9781785364112.00011.xml> accessed 26 April 2020.

71 UK Patent Act 1977, s 56(3).

72 CORREA Carlos, "Internationalization of the Patent System and New Technologies" Wisconsin International Law Journal, 20, 2001 523,541. <https://heinonline.org/HOL/Page?handle=hein.journals/wisint20\&id=533\&div=\&collection=>.

73 COHEN Wesley M and others (eds), "Patents in the Knowledge-Based Economy" National Academies Press, 200356.

74 RAMALHO (n 6) 26.

75 LIM Daryl, “AI \& IP: Innovation \& Creativity in an Age of Accelerated Change“ Akron Law Review, 52, $2018 \quad 813,864 . \quad<$ https://heinonline.org/HOL/Page?handle=hein.journals/aklr52\&id=837\&div=\&collection=>. 
of skilled person must be rise in parallel. ${ }^{76}$ Due to rapid computing and autonomous intelligence non-obvious innovation or creation for ordinary people may be obvious or procurable for AI users. ${ }^{77}$ However, raising the bar of inventiveness will be a drawback for human inventors. ${ }^{78}$

While generating inventions with AI, because of low threshold human PHOSITA won't be able to understand non- obviousness criteria and improvement will be slow. On the other hand, AI PHOSITA's obviousness rate will be much more. ${ }^{79}$ Nevertheless, due to difference between cognitive of human and AI system, if human PHOSITA cannot comprehend boundaries of AI operation, the patent claims will be invalid. ${ }^{80}$

\section{ROBOTICS}

Robot is defined by International Federation of Robotics (IFR) as activated system adjustable in axis, performing for planned goal autonomously. ${ }^{81}$ Despite of many types of robots, development in AI has increased the variety of intended fields of robots. ${ }^{82}$

Work on and develop robotics is a time consuming and costly process thus working firms need motivation to maintain this process. Ip rights play essential role for these firms to get investment, compensate R\&D costs and prevent competitors infringement. ${ }^{83}$

76 VERTINSKY Liza and RICE Todd, “Thinking about Thinking Machines: Implications of Machine Inventors for Patent Law" Boston University Journal of Science \& Technology Law, 8, 2002 574,602.<https://heinonline.org/HOL/Page?handle=hein.journals/jstl8\&id=582\&div=\&collection $=>$.

77 RAMALHO (n 6) 2.

78 FIRTH-BUTTERFIELD Kay and CHAE Yoon, “Artificial Intelligence Collides with Patent Law“ World Economic Forum, 2018 13. <https://www.weforum.org/whitepapers/artificial-intelligence-collides-with-patent-law $>$.

$79 \quad$ LIM (n 6) 52.

80 Nautilus, Inc. v. Biosig Instruments, Inc. - 572 U.S. 898, 134 S. Ct. 2120 (2014)

81 "Introduction into Service Robots" International Federation of Robotics, 20161. $<$ https://ifr.org/img/office/Service_Robots_2016_Chapter_1_2.pdf>.

82 "Artificial Intelligence in Robotics" IFR 2018 1. <https://ifr.org/downloads/papers/Media_Backgrounder_on_Artificial_Intelligence_in_Robotics_May_2018.pdf $>$.

83 KEISNER Andrew, RAFFO Julio and WUNSCH-VINCENT Sacha, "Breakthrough Technologies-Robotics, Innovation and Intellectual Property", WIPO Magazine, 30, 2015 10. <<www.wipo.int/wipo_magazine/en/ 2016/06/article_0002.html >>. 
Patent rights is significant for robotic companies in terms of capital they need to do R\&D. Also, to prevent rivals and protect profits robotics companies frequently apply for patents. Nevertheless, in the past, it has seen that just a few of many patent applications of robotics had been used in commercial area. Difficulty of rapid commercializing, the robots cause meaningless protection and award due to the short time protection patents provide. Even so, there are some disputes among robotic companies.

Over the past decade most of the conflict in the robotics area have been exposed upon iRobot. ${ }^{84}$ For instance, in iRobot Corporation v Urus Industrial Corporation Case iRobot argued that Urus' vacuum cleaner violated their patent rights and wanted to be recompensed..$^{85}$ In the end, parties reached an agreement outside of the court that violator party won't sell the product in the country until patent period ends. ${ }^{86}$ Especially design patents are important to protect due to leaving a unique mark in consumers memory. It has been deliberated by the experts that, is scope of patents too broad despite it seems patent conflicts among robotic firms have been solved effectively. ${ }^{87}$ With the autonomous features of robots, the legal liability of their actions become a concern. The autonomy of robots is a technological feature and related to the complex interplay of their environmental connections. it has been questioned that whether current legal framework of legal responsibility needs to change related to the negligence or harm of robots. One of the questions was, is it needed to create a new legal category to assess the liability of robots? Although it is stated in European Parliament recommendations that current legal framework is sufficient to draw a line for the action of robots there is no valid rules particular for robotics. ${ }^{8}$ For the infringement actions in the existing legal regimes, it is possible to hold liable the users, programmers or owners

\footnotetext{
84 ibid 16.

85 iRobot Corporation v Urus Industrial Corporation Case 1:05-cv-10914-RGS.

86 Ibid.

87 TOBE F., “The Patent Grip Loosens“"Everything-Robotics, 6, 20122012.

88 "European Parliament Resolution of 16 February 2017 with Recommendations to the Commission on Civil Law Rules on Robotics (2015/2103(INL)) AI 18.“
} 
rather than robots. ${ }^{89}$ However, it is not known that to which degree they can foresee the results of the actions of robots. It is not fair to hold the owner, programmer or user liable from the infringement actions of robots which they not able to estimate or plan. On the other hand, it is also essential to compensate the damage robots cause, it is clear that existing legal system cannot answer the questions thus it must be reconstructed.

\section{CONCLUSION}

In conclusion, in the light of disrupting advancements in the AI technology, it is clear that there are boundaries need to be reconsidered by the current patent regime which is not able keep in step with. In this article, it is evaluated that the rapid development in the AI have effects on the field of 3D printing, software and interactive robotics in terms of patentability, inventorship and infringement. Firstly, 3D printing is about to change the current economy perception. It also opens door to individual patent infringements which is costly and almost impossible to follow. It seems that to protect patent holders the only way is preventing circulation of digital files. It has not put forward the legal definition of CAD files, and concerns remain whether to what extent dissemination of them and act of intermediaries' cause patent infringement directly or indirectly. In the long run with the dissemination of $3 \mathrm{D}$ printers, the difficulties patent holders face may increase as well. ${ }^{90}$ With regard to software implemented inventions, different approaches of patentability assessment must be combined to be foreseen by inventors to prompt the future innovations. Issues of allocating inventorship and person skilled in art in the subject of AI-generate inventions must be re-evaluate. Also, the Robotic firms are making investments and paying $R \& D$ costs and, to foster innovation, it should be examined that whether the robots need to be protected by patents and who must be liable for infringement actions of robots. It is possible that there are non-disclosed innovations, due to vague approach of patent system to AI based innovations and need of knowing the last

\footnotetext{
89 ibid AD.

$90 \quad$ MIMLER (n 4) 134.
} 
3342 | Muhammet Emir ÇELIK

invention in the field in order to achieve higher technology therefore, there must be some changes in the fundamentals of patent law. 


\section{BIBLIOGRAPHY}

Actavis UK Ltd and Others v Eli Lilly and Company [2017] UKSC 48, [2018] 1 All ER 171

Agreement on Trade Related Aspects of Intellectual Property (TRIPS) 1994

Clipboard formats I/MICROSOFT (0424/03) [2006]

Computer program product/IBM (T-1173/97) [1998]

Cooper v. Goldfarb, 154 F.3d 1321, 1327 (Fed. Cir. 1998)

Diamond v. Chakrabarty 447 U.S. 303, 100 S. Ct. 2204 (1980)

European Patent Convention (EPC) 1973

Gales' Application [1991] RPC 305

Hitachi/ Merrill Lynch's Application [1989] RPC 561

HITACHI/Auction Method (T-0258/03) [2004]

IBM/Computer program product II (T-935/97) [1999]

IBM/Text processing (T-65/86) [1990] EPOR 181

iRobot Corporation v Urus Industrial Corporation [2005] 1:05 cv 10914 RGS

Jones v Pearce [1832] 1 WPC

Menashe Business Mercantile Ltd and Another v William Hill Organisation Ltd [2002] EWCA

Civ 1702, [2003] 1 WLR 1462

Nautilus, Inc. v. Biosig Instruments, Inc. 572 U.S. 898, 134 S. Ct. 2120 [2014]

PBS PARTNERSHIP/Controlling pension benefits system (T-931/95) [2000] OJ EPO 441

Programs for computers (G 03/08) EPO 2010

Rabobank New Zealand v McAnulty [2011] 3 NZLR 192 (CA)

UK Patent Act 1977

United Wire Ltd v Screen Repair Services Ltd [2001] RPC 24

VICOM/Computer-related invention (T-208/84) [1987] 1 OJEPO 14 
ABBOTT Ryan, "I Think, Therefore I Invent: Creative Computers and the Future of Patent Law“Boston College Law Review 57 (2016) 1079. <https://heinonline.org/HOL/Page?handle=hein.journals/bclr57\&id=1080\&div=\&collection $=>$

"Artificial Intelligence in Robotics" (IFR 2018) <https://ifr.org/downloads/papers/Media_Backgrounder_on_Artificial_Intelligence_in_Robotics_May_2018.pdf>

BALLARDINI, Rosa Maria, NORRGÅRD Marcus, and MINSSEN Timo "Enforcing Patents in the Era of 3D Printing" Journal of Intellectual Property Law \& Practice 10(11) (2015) 850. <https://academic.oup.com/jiplp/article-lookup/doi/10.1093/jiplp/jpv152> accessed 26 April 2020

BECHTOLD Stefan, “3D Printing, Intellectual Property and Innovation Policy" IIC - International Review of Intellectual Property and Competition Law $47 \quad$ (2016) 517. <http://link.springer.com/10.1007/s40319-016-0487-4> accessed 26 April 2020

POSNER Richard, “Do Patent and Copyright Law Restrict Competition and Creativity Excessively? "(The Becker-Posner Blog) 9(30). (2012) <https://www.becker-posner-blog.com/2012/09/do-patent-and-copyright-law-restrict-competition-and-creativity-excessively-posner.html> accessed 26 April 2020

BRADSHAW Simon, BOWYER Adrian and HAUFE Patrick, "The Intellectual Property Implications of Low-Cost 3D Printing“ A Journal of Law, Technology and Society 7 (2010) 5. <https://heinonline.org/HOL/P?h=hein.journals/scripted7\&i=5> accessed 26 April 2020

COHEN Wesley and others (eds), "Patents in the Knowledge-Based Economy“ (National Academies Press 2003)

CORREA Carlos M., "Internationalization of the Patent System and New Technologies" Wisconsin International Law Journal 20 (2001) 523. <https://heinonline.org/HOL/Page?handle=hein.journals/wisint20\&id=533\&div=\&collection $=>$ 
CUBERT Jeremy A., “The Law of Intellectual Property Created by Artificial Intelligence"in Woodrow Barfield and Ugo Pagallo, Research Handbook on the Law of Artificial Intelligence (Edward Elgar Publishing 2018) <https://www.elgaronline.com/view/edcoll/9781786439048/9781786439048.00028.xml> accessed 26 April 2020

DEPOORTER Ben, "Intellectual Property Infringements \& 3D Printing: Decentralized Piracy Symposium: The Legal Dimension of 3D Printing" Hastings Law Journal 65 (2013) 1483. <https://heinonline.org/HOL/P?h=hein.journals/hastlj65\&i=1595> accessed 26 April 2020

"European Parliament Resolution of 16 February 2017 with Recommendations to the Commission on Civil Law Rules on Robotics" (2015/2103(INL)) 18.

FIRTH-BUTTERFIELD Kay and CHAE Yoon, "Artificial Intelligence Collides with Patent Law" (World Economic Forum 2018) $<$ https://www.weforum.org/whitepapers/artificial-intelligence-collides-with-patent-law>

GOLDMAN Eric, "Fixing Software Patents" (Social Science Research Network) SSRN Scholarly Paper ID 2199180 2013.<https://papers.ssrn.com/abstract $=2199180>$ accessed 26 April 2020

GRANSTRAND Ove, “Patents and Policies for Innovations and Entrepreneurship"in Toshiko Takenaka, Research Handbook on Patent Law and Theory (Edward Elgar Publishing 2019) $<$ https://www.elgaronline.com/view/edcoll/9781785364112/9781785364112.00011.xml> accessed 26 April 2020

"Introduction into Service Robots" (International Federation of Robotics 2016) <https://ifr.org/img/office/Service_Robots_2016_Chapter_1_2.pdf>

IONITA C, "Software Patentability in Europe: The Rise of the Inventive Step Requirement" (UPPSALA UNIVERSITET 2017) 
JAFFE Adam B. and LERNER Josh, Innovation and Its Discontents: “How Our Broken Patent System Is Endangering Innovation and Progress, and What to Do About It" (Princeton University Press 2004) <https://www.jstor.org/stable/j.ctt7t655> accessed 26 April 2020

KARKHANIS Aashish R. and PARENTI Jenna L, “Toward an Automated First Impression on Patent Claim Validity: Algorithmically Associating Claim Language with Specific Rules of Law“ Stanford Technology Law Review 19 (2015) Stanford Technology Law Review $196 \quad<$ https://heinonline.org/HOL/Page?handle=hein.journals/stantlr19\&id=212\&div=\&collection $=>$

KEISNER Andrew, RAFFO Julio and WUNSCH-VINCENT Sacha, "Breakthrough Technologies-Robotics, Innovation and Intellectual Property“, vol 30 (WIPO 2015) $<<$ www.wipo.int/wipo_magazine/en/ 2016/06/article_0002.html >>

KITCH Edmud W., "Graham v. John Deere Co.: New Standards for Patents" Journal of the Patent Office Society 49 (1967) 237 $<$ https://heinonline.org/HOL/P?h=hein.journals/jpatos49\&i=263> accessed 26 April 2020

LIM Daryl, “AI \& IP: Innovation \& Creativity in an Age of Accelerated Change" Akron Law Review 52 (2018) 813 <https://heinonline.org/HOL/Page?handle=hein.journals/aklr52\&id $=837 \&$ div $=\&$ collection $=>$

MENDIS Dinusha, “The Clone Wars”: Episode 1: “The Rise of 3D Printing and Its Implications for Intellectual Property Law - Learning Lessons from the Past?" EIPR: European Intellectual Property Review 35 (2013) 155

MIMLER Marc D., “3D Printing, the Internet and Patent Law - A History Repeating?" (Social Science Research Network 2013) SSRN Scholarly Paper ID $2482551<$ https://papers.ssrn.com/abstract $=2482551>$ accessed 26 April 2020 
MIMLER Marc D., “3D Printing and Patent Law - a UK Perspective: Apt and Ready? "in Dinusha Mendis, Mark Lemley and Matthew Rimmer, "3D Printing and Beyond" (Edward Elgar Publishing 2019) $<$ https://www.elgaronline.com/view/edcoll/9781786434043/9781786434043.00012.xml> accessed 16 May 2020

OSBORN Lucas S., “3D Printing and Intellectual Property“ (1st edn, Cambridge University Press 2019) <https://www.cambridge.org/core/product/identifier/9781316584507/type/book> accessed 26 April 2020

RAMALHO Ana, "Patentability of AI-Generated Inventions: Is a Reform of the Patent System Needed? " (Social Science Research Network 2018) SSRN Scholarly Paper ID $3168703<$ https://papers.ssrn.com/abstract $=3168703>$ accessed 26 April 2020

RAVID Shlomid Yanisky and LIU Xiaqiong, “When Artificial Intelligence Systems Produce Inventions: An Alternative Model for Patent Law at the 3A Era" Cardozo Law Review 39 (2018) 2215

RUSSEL Stuart and NORVIG Peter, “Artificial Intelligence: A Modern Approach" (Pearson Education Limited 2013)

SHEMTOV Noam, "A Study on Inventorship in Inventions Involving AI Activity" (Queen Mary University of London 2019)

BENTLY, Sherman, et al. "Exclusions from Patentability and Exceptions and Limitations to Patentees' Rights" (WIPO Standing Committee on the Law of Patents 2010) SCP/15/3 Annex 2 $<$ https://www.wipo.int/edocs/mdocs/patent_policy/en/scp_20/scp_20_3.pdf>

SOANS Cyril A., "Some Absurd Presumptions in Patent Cases" Patent, Trademark and Copyright Journal of Research and Education 10 (1966) $433 \quad<$ https://heinonline.org/HOL/Page?handle=hein.journals/idea10\&id $=435 \&$ div $=\&$ collection $=>$

SUTTON Eric, “Artificial Intelligence 2.0: Artificially Intelligent Guidance For Obtaining Artificial Intelligence Patents, as Presented to 
IPO (3-7-18) “<http://www.patnotechnic.com/2018/04/artificialintelligence-20-artificially.html $>$ accessed 26 April 2020

TOBE Frank, “The Patent Grip Loosens" (2012) 6 Everything-Robotics 2012

VAN OVERWALLE Geertrul and LEYS Reinout, “3D Printing and Patent Law: A Disruptive Technology Disrupting Patent Law? “ IIC International Review of Intellectual Property and Competition Law 48 (2017) $504<$ http://link.springer.com/10.1007/s40319017-0602-1> accessed 26 April 2020

VERTINSKY Liza and RICE Todd M., “Thinking about Thinking Machines: Implications of Machine Inventors for Patent Law“ Boston University Journal of Science \& Technology Law 8 (2002) $574<$ https://heinonline.org/HOL/Page?handle=hein.journals/jstl8\&id $=582 \&$ div $=\&$ collection $=>$

WHADCOCK Ian, "A Third Industrial Revolution" The Economist $<$ https://www.economist.com/special-report/2012/04/21/athird-industrial-revolution> accessed 26 April 2020 